\title{
P02.140. Comparing the effect of ozonated olive oil to clotrimazole cream in the treatment of vulvovaginal candidiasis
}

\author{
F Tara, Z Zand-Kargar* , O Rajabi, F Berenji, H Azizi \\ From International Research Congress on Integrative Medicine and Health 2012 \\ Portland, Oregon, USA. 15-18 May 2012
}

\section{Purpose}

Vulvovaginal candidiasis is the most common infection of the vulvovagina which manifests with itching, burning sensation and leucorrhea. Conventional treatments are azoles to which tolerance has been reported, especially in immunosuppressed patients. New studies suggest antifungal effects of ozone, the allotropic form of oxygen. This study compared the effects of ozononated olive oil and clotrimazole in the treatment of vulvovaginal candidiasis.

\section{Methods}

One hundred patients with confirmed vulvovaginal candidiasis were randomly classified to two groups and treated by ozonated olive oil or clotrimazole for 7 days. The study outcomes were changes in itching, burning, leucorrhea and culture before and after the treatment, which were evaluated by an interview and paraclinical examination. Statistical analysis was done by SPSS software, version 17 . The significance level stood at 0.05 .

\section{Results}

Ozone and clotrimazole both reduced the symptoms significantly and led to negative specimen cultures $(\mathrm{p}<0.05)$. There was no significant difference between the two groups in their effect on itching, leucorrhea and culture ( $p>0.05)$. However, ozone decreased burning sensation significantly better than clotrimazole $(\mathrm{p}<0.05)$.

\section{Conclusion}

Considering the potential efficacy of ozonated olive oil for the improvement of clinical and paraclinical aspects of patients with vulvovaginal candidiasis, it could be

Mashhad University of Medical Sciences, Mashad, Iran suggested as an effective topical treatment for these patients.

Published: 12 June 2012

doi:10.1186/1472-6882-12-S1-P196

Cite this article as: Tara et al:: P02.140. Comparing the effect of ozonated olive oil to clotrimazole cream in the treatment of vulvovaginal candidiasis. BMC Complementary and Alternative Medicine 2012 12(Suppl 1):P196.
Submit your next manuscript to BioMed Central and take full advantage of:

- Convenient online submission

- Thorough peer review

- No space constraints or color figure charges

- Immediate publication on acceptance

- Inclusion in PubMed, CAS, Scopus and Google Scholar

- Research which is freely available for redistribution
C 2012 Tara et al; licensee BioMed Central Ltd. This is an Open Access article distributed under the terms of the Creative Commons Attribution License (http://creativecommons.org/licenses/by/2.0), which permits unrestricted use, distribution, and reproduction in any medium, provided the original work is properly cited. 